\title{
A Managerial Guide to Products Liability: \\ A Primer on the Law in the United States-PART II \\ A Focus on Theories of Recovery
}

\author{
Richard J. Hunter, Jr. (Corresponding Author) \\ Department of Economics and Legal Studies \\ Seton Hall University, South Orange, New Jersey, United States 07079 \\ Telephone: 973-761-9511 \\ E-mail: hunterri@shu.edu \\ Henry J. Amoroso \\ Department of Economics and Legal Studies \\ Seton Hall University, South Orange, New Jersey, United States 07079 \\ E-mail: Henry.Amoroso@shu.edu \\ John H. Shannon \\ Department of Economics and Legal Studies \\ Seton Hall University, South Orange, New Jersey, United States 07079 \\ E-mail: John.Shannon@shu.edu
}

Accepted: April 11, 2012 Published: May 07, 2012

Doi:10.5296/ijld.v2i3.1777 URL: http://dx.doi.org/10.5296/ijld.v2i3.1777

\begin{abstract}
In Part II, the authors build on Part I of this study and here focus on the theories implicit in a product liability claim: negligence, fraud and misrepresentation, and warranty - with a focus on their inherent weaknesses-leading to the creation of the now preferred theory of strict liability in tort. The context of Part II is on the common cases that provided the theoretical basis for the underlying theories, as well as to the development of strict liability.
\end{abstract}

Key words: Theories of liability, negligence, warranty, fraud, strict liability

\section{Introduction}

Originally, there were few sellers in the market place, so cases involving a product defect were decided on the basis of the theory of absolute liability against the manufacturer. 
As manufacturing capabilities increased, a negligence theory was adopted, but this led to enormous exposure on the part of the "new manufacturing class" developing in England in the Industrial Revolution. English courts developed a theory in tort cases, highly favorable to the "new industrial class" (found in the case of Winterbottom v. Wright, 152 Eng. Rep. 402 (1842), that determined the scope of the manufacturer's duty. The court in Winterbottom held that a duty of a manufacturer to show reasonable care would only extend to the party with whom the manufacturer had actually dealt through its contract. Since a buyer rarely dealt with a manufacturer, no direct relationship existed between the manufacturer and the buyer. Hence, the manufacturer had no duty of due or reasonable care to the buyer because to "privity of contract" existed.

On the other hand, since the buyer had dealt with the retailer in purchasing a chattel (the common law term for an item of personal property), could the buyer sue the retailer? As a factual matter, in most cases the buyer had been injured by a defect in the product not caused by any action or negligence on the part of the retailer - the retailer had only "passed on" the manufacturer's product. So, the buyer was effectively barred from recovery against the retailer on a negligence theory and against the manufacturer on ground that the consumer was not in privity with the manufacturer. This was the origin of the doctrine termed caveat emptor, or "let the buyer beware!" which was the "watch phrase" of the emerging common law of the industrial age.

Two early exceptions were created by English courts. In 1852, a decade after Winterbottom v. Wright, an American court decided the case of Thomas v. Winchester, 6 N.Y. 397 (1852), which determined that for products termed "negligently labeled products" (in this case, poisons), the manufacturer could not limit its liability through the defense of privity. Later, Loop v. Litchfield, 42 N.Y. 351 (1970), recognized the inherent unfairness and practical limiting nature of the doctrine of privity. The court extended the limitation on applying the privity doctrine to the range of "imminently dangerous products" such as poisons, explosives, deadly weapons, and the like."

The doctrine of privity was finally severely limited - some say obliterated - in Judge (later Justice) Cardozo's opinion in the case of MacPherson v. Buick Motors, 217 N.Y. 382 (1916), a case arising in the Court of Appeals in New York.

\subsection{Case Studies: MacPherson and Henningsen}

In MacPherson, the manufacturer was first found to be negligent on the basis that it could have discovered defects in the construction of wooden wheels by and through a reasonable inspection of the wheels which it had failed to do! The court noted that wooden wheels were not "inherently dangerous" products but that any product is likely to be dangerous if it is negligently made. The court then extended the duty of the manufacturer to those persons who would be foreseeable users within the vertical marketing chain, without a showing of privity, in the case of all potential products negligently constructed or made. Since it was 
foreseeable that others besides the retailer would use the product, the buyer (MacPherson) was a "foreseeable party" and should be permitted to bring suit.

The issue of privity in a warranty action was raised in the case of Henningsen $v$. Bloomfield Motors, 32 N.J. 358 (1960). The case involved both the issue of vertical privity (now settled by MacPherson) and horizontal privity, since it was Mrs. Henningsen who was seeking recovery for her personal injury and Mrs. Henningsen was not the purchaser of the automobile.

The manufacturer had argued that since it was not a party to the sale (contract) by the dealer to Mr. Henningsen, there was no privity of contract between it and the plaintiff. The absence of privity eliminates the existence of any warranty from the manufacturer to $\mathrm{Mr}$. Henningsen, except that which was expressly given by the manufacturer. Thus, no implied warranty would be applicable. However, based on the rationale of MacPherson, the court rejected the requirement of privity in such contract-warranty actions and found that $\mathrm{Mr}$. Henningsen was in fact covered by the warranty provision- despite the lack of privity.

The court then turned its attention to the claims of Mrs. Helen Henningsen. Clearly, Mrs. Henningsen was not the purchaser of the automobile. However, the court extended protection to Mrs. Henningsen horizontally by the following formulation, in effect, also extending liability to all persons who:

"Within the reasonable contemplation of the parties to the warranty might be expected to become a user of the automobile."

The Henningsen rule of extending horizontal privity may be found in the original text of U.C.C. Section 2-318:

A seller's warranty, whether express or implied, extends to any natural person who is in the family or household of his buyer or who is a guest in his home if it is reasonable to expect that such person may use, consume or be affected by the goods and who is injured in person by breach of the warranty. A seller may not exclude or limit the operation of this section.

U.C.C. Section 2-318 was later further extended to "other parties" as the law of warranties itself further developed. We shall consider these "extensions" in our detailed discussions of warranty actions.

\section{Negligence, Causation, and Res Ipsa Loquitur}

In Hall v. E.I DuPont, 237 F.2d 145 ( $4^{\text {th }}$ Ct. 1956), the court noted: "A manufacturer's duty to produce a safe product, with appropriate warnings and instructions where necessary, rests initially on the responsibility each of us bears to exercise care to avoid unreasonable risks 
of harm to others." Another formulation of the concept reads: "Negligence is the omission or failure to do something which a reasonable man would do or doing something which a reasonable and prudent man would not do under the same or similar circumstances."

In general, negligence involves proof of unreasonable conduct, which is the cause in fact, and proximate cause (legal cause) of damage or injury to the plaintiff. The plaintiff must both plead and prove that specific acts or omissions of the defendant were negligent.

Negligence can arise in numerous ways and standard principles of negligence now apply fully and clearly to individuals who design, manufacture, and sell products. These areas include inadequate inspection, processing, packaging, warning, design, or marketing of products, or of the service portion of a transaction involving a good. Look at the jury instructions found in Garnes v. Gulf \& Western Manufacturing Co. 789 F.2d 637 (8 ${ }^{\text {th }}$ Cir. 1985):

"You are instructed that it is the law that the manufacturer of a machine has a nondelagable duty to make a machine that includes necessary safety devices. You are instructed that it is the law that the manufacturer has a duty to produce a safe product with warnings and instructions where necessary."

Courts will employ the standard of the reasonable man or the reasonable person in the position of the manufacturer, or designer, or marketer. In products cases, Wilson v. Piper Aircraft, 282 Ore. 411 (1978), reminds us that expert testimony or proof will be required in most cases - and absolutely in any case involving medical malpractice, or medical negligence, where an expert would testify what a reasonable medical practitioner in the same or similar community under the same or similar circumstances would or would not do. The court concluded:

"We conclude that the plaintiff had the burden to prove by expert medical evidence what a reasonable medical practitioner of the same school and same or similar community under the same or similar circumstances would have disclosed to his patient about the risks incident to a proposed diagnosis or treatment, that the physician departed from that standard, causation, and damages."

The standard for a manufacturer in a design case is a simple one: Did the manufacturer exercise all reasonable skill and knowledge concerning the design of the product as would other designers under the same or similar circumstances. A manufacturer must keep abreast of recent scientific and technological developments, and may be required to conduct tests or research to learn about any inherent dangers in their products. (Taylor v. Wyeth Labs, 139 Mich. App. 389 (1984), indicates that a manufacturer will be held accountable under a standard of "professional skill and knowledge.") A manufacturer is held to such reasonable skill, knowledge, and diligence as that of the experts in the filed to design and produce a product that is reasonably safe for its intended and foreseeable use. Ignorance of risks which 
were scientifically knowable or known at the time of sale or manufacture, or design; and failure to act is no defense and may, in itself, constitute negligence as an omission.

The Restatement, Section 395, and Comment F embody this principle:

A manufacturer who fails to exercise reasonable care in the manufacture of a chattel which, unless carefully made, he should recognize as involving an unreasonable risk of causing physical harm to those who use it for a purpose for which the manufacturer should expect it to be used and those whom he should expect to be endangered by its probable use, is subject to liability for physical harm caused to them by its lawful use in a manner and for a purpose for which it is supplied.

The particulars are (1) the adoption of a formula or plan which, if properly followed, will produce an article safe for the use for which it is sold, (2) the selection of material and parts to be incorporated in the finished article, (3) the fabrication of the article by every member of the operative staff no matter how high or low his position, (4) the making of such inspections and tests during the course of manufacturer and after the article is completed as the manufacturer should recognize as reasonably necessary to secure the production of a safe article, and (5) the packing of the article so as to be safe for those who must be expected to unpack it.

\subsection{Negligence of a Manufacturer in "Duty to Warn" Cases}

Generally, there is no duty to warn for patent or obvious dangers; in latent defect cases, there is such a duty. This dichotomy goes back to the "consumer expectations test" that we have previously discussed: If the defect or danger is patent or obvious, a manufacturer will not be required to issue a warning because the consumer has no expectation of receiving a warning and the consumer would not really receive anything of value or importance in the warning that he does not already know.

The issue of "to whom is the duty owed" was discussed in the famous Palsgraf case. Judge Cardozo adopted a restrictive view in his "foreseeability" formation. In contrast, Judge Andrews, who served on the New York State Court of Appeals with Justice Cardozo, viewed the matter as one of causation and not duty and adopted the "direct connection" test, with its "practical limitations in both time and space." According to Judge Cardozo, this issue is one for the court to decide as a matter of law; according to Judge Andrews, the issue is always one for the jury!

\subsection{Res Ipsa Loquitur: "Explain or Pay!"}

Res ipsa loquitur is a theory under which negligence may be proved through circumstantial evidence, where the plaintiff is unable to show any specific acts of negligence. 
The application of res ipsa permits the court to shift the burden of proof to the defendant to explain his/her conduct in an attempt to avoid the implications of liability.

The Escola case (an exploding bottle case) discussed the issue of the application of res ipsa loquitur (Escola v. Coca Cola Bottling Co. of Fresno, 24 Cal. 2 d 453 (1944)). In order to apply the doctrine, two conditions must be met:

- The defendant must have exclusive control over the thing causing injury (at least at the time it was made, in the case of a product);

- The accident is of such a nature that it would not ordinarily occur in the absence of "some" negligence.

The plaintiff must prove that the condition of the instrumentality had not been changed after it left the defendant's possession and that the plaintiff him/herself had exercised "reasonable care. At this point, the burden of proof is shifted to the defendant to show that he/she was not negligent, since the defendant has superior knowledge so as to make it reasonable for him to come forward with the required proof. Notice the concurring opinion of Justice Traynor alluding to absolute liability, a theory not formally adopted until 1963! It has been said that strict liability may be based on the same inferences as is res ipsa!

Section 328D of the Restatement of Torts sets forth the following as a statement of the elements of proof of res ipsa loquitur:

"It may be inferred that harm suffered by the plaintiff is caused by negligence of the defendant when a) the event is of a kind which ordinarily does not occur in the absence of negligence; b) other responsible causes, including the conduct of the plaintiff and third person, are sufficiently eliminated by the evidence; and c) the indicated negligence is within the scope of the defendant's duty."

\subsection{Causation}

In strict liability and negligence cases, the plaintiff must prove that the product defect was a cause in fact of the injury. The issue of causation (causation in fact or legal cause) is a very difficult issue in negligence cases. Under Section 431, the plaintiff must prove that the negligent conduct is the "legal cause" of the harm to another. This is determined by showing:

- The defendant's conduct is a "substantial factor" in bringing about the harm, and

- There is no rule of law or legal excuse relieving the actor from liability (i.e., no defense exists).

In some cases, the word "proximate" is used in connection with the issue of causation. This formulation comes from Lord Chancellor Bacon who said: "In jure, non remota causa sed proxima, spectatur!" There are two traditional formulations of the proximate cause test: 
- "But for" or "sine qua non": This is the basic, common sense test, still used by most courts. The plaintiff must prove that the injury would not have occurred had there not been the negligent act or omission of the defendant, or if the product defect had not existed. This is essentially a negative test: "The defendant's conduct is not a cause of the event if the event would have occurred without it."

- If two or more factors exist (two or more possible causes), then courts use the "substantial factor" test to determine if both parties have caused the injury. This test is sometimes used where there are concurrent causes-where two or more factors come together to cause an injury. In DeLuryea v. Winthrop Laboratories, 697 F.2d 222 ( $8^{\text {th }}$ Cir. 1983), an inadequate warnings case, the court used the term "proximate cause" and stated that each cause may "contribute" to the plaintiff"s harm.

It is important to note that one of the causes need not be the "sole" cause of the injury - just that it has "contributed" as a substantial factor to the plaintiff"s injury. In a case where a court has found concurrent causes of a plaintiff's injury, both parties are jointly and severally liable for any injury. What this means is that the plaintiff may look to both defendants jointly for the damage (joint liability). A jury may decide to apportion damages to reflect each party's percentage of liability or fault if that is a practice in an individual state proceeding. The rule also permits a plaintiff to seek recovery from one defendant, in effect, holding that one party responsible for paying the entire judgment (several liability), leaving it to a defendant to seek compensation from a joint tortfeasor.

\subsection{Intervening Cause}

Might an intervening cause that occurs after the initial negligent act serve to "cut off" the liability of the original negligent actor or tortfeasor? This aspect of causation involves foreseeing "the normal consequences created by an actor's negligent conduct." Several events are generally considered to be "within the area of foreseeable conduct" and thus would not terminate the responsibility of the original actor for their consequences. Such cases include:

- Rescue cases: Suppose that a rescuer is injured coming to the aid of an injured plaintiff? A little background is in order. First, there was a strange anomaly in the law regarding rescuers under the common law. Under the common law, so-called "lay" (nonprofessional/volunteer) rescuers who were themselves injured by the same defective product are considered as "foreseeable plaintiffs" and thus the rescuer could bring a suit in products liability against the manufacturer of the product that was defective. However, a majority of courts denied recovery to a professional rescuer, simply on policy grounds. Concerning the issue of injury to either a lay or professional rescuer by the negligent act of a third party during the 
rescue, it appears that such an injury is foreseeable as to both professional and non-professional rescuers and would not be considered as an intervening cause.

- Subsequent injury or illness to a plaintiff caused by the plaintiff's weakened condition has been held to be foreseeable.

- Efforts by the plaintiff to avert harm are seen as reasonably foreseeable.

- Even subsequent negligent medical treatment by a third party has been held to be foreseeable and thus not intervening.

\subsection{Contribution and Indemnity}

In looking at the issue of joint and several liability, a distinction must be drawn with the concept of contribution. Contribution is a rule that distributes the loss among the various tortfeasors by requiring each to pay his/her proportional share, based on their percentage of liability. Contribution is accomplished through a process called impleading, seeking to force a party to pay their rightful share of any judgment.

Indemnity is a legal principle that shifts the loss from one tortfeasor who has been compelled to pay despite the lack of any fault to the shoulders of another who should bear it instead. This may be accomplished by a contractual provision providing for indemnity or through operation of law.

Both contribution and indemnity are raised in the context of joint and several liability, where the plaintiff may bring suit against parties separately, or all of them together, at his/her option.

\section{Misrepresentation and Fraud}

The basic distinction between misrepresentation and fraud lies in the presence or absence of scienter, or the intent to deceive. Thus, a misrepresentation without scienter is sometimes termed as an "innocent misrepresentation" to distinguish it from actionable fraud. A second major distinction lies in the fact that if a party can prove actionable fraud (as opposed to mere misrepresentation), then that party can collect punitive damages to punish the defendant for his intentional conduct. In a normal case, damages may be awarded which reflect the difference between the value of the item as received and the value of the item represented (so-called "benefit of the bargain" damages). Or, a party may choose to simply rescind the contract; or rescind the contract and seek damages under the remedy of cover (going into the market place to purchase a "reasonable substitute good").

The causes of action of misrepresentation and fraud were essentially a hybrid of both contract and tort law, but which evolved as a contract action for a buyer who was dissatisfied 
with the bargain he or she had entered into. To establish a common law action in fraud, a plaintiff must prove four elements:

- That the defendant made a false representation of a material fact; [through words, actions known as concealment, or through silence, where there is a duty to speak];

Generally, there is no "duty to speak" in a traditional "arms length" business transaction. However, a "duty to speak" will be found in the following circumstances:

- In the sale of a home or other real property, many courts (most especially California and Colorado) require "full disclosure" of any and all "material defects" or important facts known by the defendant;

- In a "fiduciary relationship" [a relationship of trust and confidence between the parties such as broker-client, partners in a business, etc.] there is a duty of full disclosure of all important financial facts or information that might impact on an individual's decision to invest;

- To correct a prior misstatement or where a party gives a false impression by revealing some facts and withholding others (Bergeron v. Dupont, 116 N.H. $373(1973))$.

- That the defendant knew the statement was false (knowledge of falsity), knew that he had no knowledge of its truth or falsity (reckless disregard of the truth), or knew that he did not have as strong a basis for his statement as he implied; [scienter]

- That the defendant intended the plaintiff to rely on the statement and that the plaintiff justifiably relied on the statement; and

- That the plaintiff suffered damage.

To be actionable, a representation must be one of fact rather than of opinion. Statements merely of quality or value (or other common forms of "sales talk") constitute "sales puffing" and are generally not actionable. Exceptions occur where these "commendations" or opinions are made by a party with "superior knowledge" (an expert's opinion, as was characterized in Vokes v. Arthur Murray, 212 So. 2d 906, D.C. Appl. Fla. (1968), or where the parties "were not on equal footing" (as in Sellers v. Looper, 264 Ore. 12 (1972) -statements made by a real estate agent included the phrase "a good well"). Predictions of future events or opinions as to future contingencies are generally not actionable, unless the speaker purports to have special or unique knowledge. 
Statements regarding matters of law were generally held to be opinions rather than facts (Puckett Paving v. Carrier Leasing, 236 Ga. 891 (1976) — under the common law, "everyone is presumed to know the law"), except:

- When they are intended to be statements of fact and are understood as such;

- When a special relationship of "trust and confidence" exists between two parties (lawyer-client, accountant-client) and the statement is made in the context of that relationship;

- When the defendant represents himself to have "special knowledge" of the law (professionals such as estate planners, insurance salesmen, tax professionals, etc.). Today, in cases of a presumed misrepresentation of a matter of law, it is now "settled or good law" that "statements made by a professional in a professional setting as to a matter of law are generally held to be actionable" under Yorke v. Taylor, 356 Mass. 42 (1969).

To be actionable, a representation of fact must be material. The test of materiality is whether the statement "would be important to a reasonable person" - an objective standard. This requirement of materiality is designed to prevent a party from using a trivial misrepresentation as an excuse to set aside a bargain that appears to be unwise or "bad" in retrospect!

In a products case, a statement is material if it significantly affects the manner in which the plaintiff used the product, thereby increasing its danger. A statement concerning safety, for example, would be such a material assertion.

Justifiable reliance would not lie where the plaintiff knows the truth of a statement, or in the case of goods, where a reasonable inspection would have turned up the falsity of any assertion or statement, the plaintiff had the opportunity to conduct such an inspection, and fails to do so. In the case of an inspection, a plaintiff would not be required to engage in an inspection if such an activity would prove to be unduly burdensome or costly.

The element of justifiable reliance creates the anomaly of the character "Joe Isuzu," an over-the-top TV pitchman, who intentionally exaggerated just about every aspect of the product he was touting. Sometimes the more a person lies (misrepresents) the least likely a court would find justifiable reliance on the part of the plaintiff!

Section 402B of the Restatement of Tort is a second theory of recovery in tort:

"One engaged in the business of selling chattels, who, by advertising, or otherwise, makes to the public a misrepresentation of a material fact concerning the character or quality of a chattel sold by him is subject to liability for physical harm to a consumer of the chattel caused by justifiable reliance upon the misrepresentation..." 
As in common law actions for fraud or misrepresentation, the plaintiff under Section 402B must prove justifiable reliance. Justifiable reliance will not lie "where the misrepresentation is not known, or there is indifference to it, or it does not influence the purchase or a party's subsequent conduct." (Comment $\mathrm{j}$ ) The same standards apply under Section 402B as do in the case of the contractual remedy; that is, if a person is aware of the truth of any misstatement, that person cannot recover. Likewise, some courts have held that if a reasonably prudent person would have been aware of the facts or would have investigated further, that person cannot recover. Any statement, however, does not have to be the "sole inducement to purchase..." but only that it be a "substantial factor in the inducement." This is generally a question of fact for a jury to determine.

\section{Warranty Actions}

Warranty actions are preferable if a plaintiff suffers pure economic damage (especially if only the product itself is defective) and suffers no personal injury. Warranty can also be used as a theory of recovery where there is personal injury to the plaintiff. Three aspects of warranties go back to their early tort and contract roots:

(1) Warranties can arise as a matter of law (i.e., can be implied) regardless of whether the parties intended to create them;

(2) Because of its contractual nature, parties may disclaim warranties under certain circumstances or limit the remedies available for breach;

(3) The plaintiff is required to give prompt notice of breach of warranty to the seller (this was later termed the "booby trap for the unwary" by Justice Traynor-which led to the creation of strict liability in tort).

Common law recognized three separate types of sales warranties: the express warranty, the implied warranty of merchantability, and the implied warranty of fitness for a particular purpose. These warranties were codified first into the Uniform Sales Act (1906) and later into Article 2 of the Uniform Commercial Code (1961), which all states have now adopted! In the development of the warranty aspects of the UCC, no case could have been more important than Henningsen v. Bloomfield Motors, 32 N.J. 358 (1960), in which the court gave the victim of an automobile accident a remedy against the defendant-manufacturer even though she was not in privity of contract with the defendant-manufacturer. The court also refused to enforce the disclaimer and remedy limitation in the "standard form" ("boilerplate") contract on the grounds that the limitation would be unconscionable under UCC Section 2-302.

The warranty provisions of Article 2 apply only to the "sale of goods." Section 2-106(1), defines a sale as "the passing of title from the seller to the buyer for a price." Goods are defined (Section 2-105) as all "things movable and tangible...." Consequently, transactions in "goods" other than sales (leases and bailments) were not governed by the original Article 2 warranty provisions. That coverage was specifically added in the addendum 
to Article 2, relating to bailments. In addition to Article 2 coverage, warranties may, however, be governed by strict liability or by common law warranties that still survive under state law.

\subsection{Express Warranty: (Section 2-313)}

"Express warranties by the seller are created as follows:

a. Any affirmation [statement] of fact or promise made by the seller to the buyer which relates to the goods and becomes part of the basis of the bargain creates an express warranty that the goods shall conform to the affirmation or promise.

b. Any description of the goods which is made part of the basis of the bargain creates an express warranty that the goods shall conform to the description.

c. Any sample or model which is made part of the basis of the bargain creates an express warranty that the whole of the goods shall conform to the sample or model."

As to any specific language required under the Code to create an express warranty:

"It is not necessary to the creation of an express warranty that the seller use words such as "warrant" or "guarantee" or that he have a specific intention to make a warranty, but an affirmation merely of the value of the goods or a statement purportedly to be merely the seller's opinion or commendation of the goods does not create a warranty."

\subsubsection{Notes on Express Warranties:}

- A sample is actually drawn from the bulk of goods which is the subject matter of the sale; a model is not drawn from the bulk of goods and is offered for inspection by a seller or salesperson when the subject matter is not at hand.

- The "affirmation of fact or promise" or a description of goods is usually made in words; however, they can also be made by pictures or other forms of communication (such as advertising on radio and TV).

- Courts use the analysis under misrepresentation and fraud for the distinctions between fact and opinion, fact and commendation, etc.

- A promise or affirmation of fact must "relate to the goods." Promises unrelated to the goods ("This car will make you popular with chicks") do not create warranties.

- Once an affirmation of fact or promise is made, or a description given, or sample or model shown, the presumption is that such affirmation, promise, description, sample, or model is intended to be a basis of the bargain. 
- Unlike an action for misrepresentation or fraud, no particular reliance is required in order to create a warranty; likewise, no particular intention is required to create the warranty. We focus, instead, on the words of the seller in creating an express warranty.

- Comment 7 to Section 2-313 provides that "post-sale" representations may be considered as part of the bargain - especially those concerning safety-where such statements would give the buyer a false sense of security or might cause the buyer not to be vigilant or not to return goods. This is a "public policy" consideration.

- Section 2-313 does not require that an express warranty be in writing; however, express warranties are subject to the parol evidence rule of Section 2-202 (if there is a writing that was intended to be the final expression of agreement between the parties, the express warranty could not "contradict" the writing but could "explain or supplement" any such writing with a "consistent additional term.") The Statute of Frauds (Section 2-201) may also apply if the contract was for sale of goods for $\$ 500$ or more [ $\$ 5,000$ under the proposed revisions] and may require that a warranty be in writing.

- The express warranty is applicable to all sellers-merchants and non-merchants alike! However, the warranty is only applicable to one who makes the statement. Thus, a retailer is not automatically liable for a manufacturer's express warranty. If a retailer repeats the manufacturer's warranty as a part of a sales promotion, the retailer now becomes liable.

\subsection{Implied Warranty of Merchantability (Section 2-314)}

The warranty of merchantability is perhaps the most important of all the warranty protections!

"Unless excluded or modified, a warranty that the goods shall be merchantable is implied in a contract for their sale if the seller is a merchant with respect to goods of that kind. Under this section, serving for value food or drink to be consumed either on the premises or elsewhere is a sale."

Goods to be merchantable must be at least such as:

a. Pass without objection in the trade under the contract description; and

$b$. In the case of fungible goods, are of fair average quality within the description; and

c. Are fit for the ordinary purpose for which such goods are used; and

d. Run, within the variations permitted by the agreement, of 
even kind, quality and quantity within each unit and among all units involved; and

d. Are adequately contained, packaged, and labeled as the agreement may require; and

e. Conform to the promises or affirmations of fact made on the container or label if any."

\subsubsection{Notes on the Implied Warranty of Merchantability}

- Merchantability is not equated with perfection, and thus is not a strict liability standard, in that sense. However, it is not normally a defense to a claim of breach of the warranty of merchantability that the seller could not have done anything to detect or prevent the defect.

- "Fair average quality" is a term appropriate to agricultural bulk products and means goods centering on the middle belt of quality, not the least or the worst. A fair percentage of the least (as determined by the trade usage, course of dealings, etc.) is permissible but the goods are not of "fair average quality" if they all are of the least or worst quality possible.

- "Fitness for the ordinary purposes for which goods of the type are used" is the fundamental concept of the warranty of merchantability. A determination of a product's ordinary purpose depends on the circumstances of each case.

- The goal of subsection (f) is that goods must conform to the representations found on their labels. Even if a consumer failed to read the label (and hence, there could be no express warranty), a violation of the implied warranty of merchantability might still obtain.

- Comment 3 provides that "a contract for secondhand [used] goods...involves only such obligation as is appropriate to such goods." Thus, while a warranty of merchantability is possible, the extent of that warranty would probably be one for a jury.

- The definition of merchant is a narrow one and the warranty of merchantability is applicable only to a person who, in a professional status, sells a particular kind of goods giving rise to the warranty. (UCC Section 2-104 and Siemen v. Alden, 34 Ill. App. 3d 961 (1975)). A person making an isolated sale of goods is not a merchant. There is a split of decisions regarding whether or not a farmer is or is not a merchant with respect to Section 2-104 and thus Section 2-314 as a matter of law. This determination is left to a case-by-case basis.

\subsection{Implied Warranty of Fitness for a Particular Purpose (Section 2-315)}

"Where the seller at the time of contracting has reason to know any particular purpose for which the goods are required and that the buyer is relying on the seller's skill or judgment to select or furnish suitable goods, there is unless excluded or modified under the next 
section an implied warranty that the goods shall be fit for such purposes."

\subsubsection{Notes on the Warranty of Fitness}

- There are two requirements for this warranty:

- The seller has "reason to know" of the use for which the goods are purchased;

- The buyer must rely on the seller's expertise in supplying the proper product. (Lewis v. Mobil Oil, 438 F.2d $500\left(8^{\text {th }}\right.$ Cir. 1971)). This is a question of fact to be determined by looking at the circumstances of the transaction and the specific requests or words used by the parties.

- The warranty of fitness applies to merchants and non-merchants alike. However, it only applies to a person who created the warranty and not to all suppliers within the marketing chain.

- The specificity with which the buyer ordered the goods is also a factor in determining whether the buyer relied on the seller's expertise. A buyer's claim is weakened if the buyer has control over the detailed specifications of the goods. Likewise, if the buyer examined the goods, he is less likely to have relied on the seller's judgment in furnishing the goods.

\subsection{Persons to be Protected: The "New Privity"}

Section 2-318-Third Party Beneficiaries of Warranties (horizontal privity)

Alternative A: A seller's warranty whether express or implied extends to any natural person who is in the family or household of his buyer or who is a guest in his home if it is reasonable to expect that such a person may use, consume or be affected by the goods and who is injured in person by breach of the warranty. A seller may not exclude or limit the operation of this section.

Alternative B: ...extends to any natural person who may be reasonably expected to use, consume or be affected by the goods and who is injured in person by breach of the warranty. A seller may not exclude or limit the operation of this section.

Alternative $C$ : ... extends to any person who may reasonably be expected to use, consume or be affected by the goods and who is injured by the breach of the warranty. A seller may not exclude or limit the 
operation of this section with respect to injury to the person of an individual to whom the warranty extends.

\subsubsection{Notes on the Extension of Horizontal Privity}

- The last sentence of each alternative forbids the exclusion of liability to the persons to whom the warranties are made under each section.

- Alternative A is the Henningsen principle and is by far the most popular of the alternatives.

"Accordingly, we hold that under modern marketing conditions, when a manufacturer puts a new automobile in the stream of trade and promotes its purchase to the public, an implied warranty that it is reasonably suitable for use as such accompanies it into the hands of the ultimate purchaser... We are convinced that the cause of justice in this area of law can be served only by recognizing that she (Mrs. Henningsen) is such a person who, in the reasonable contemplation of the parties to the warranty, might be expected to become a user of the automobile. Accordingly, her lack of privity does not stand in the way of prosecution of the injury suit against the defendant Chrysler."

- Some states are still quite strict in some aspects of vertical privity regarding warranties. An express warranty, for example, is based upon the express words or statements made by a particular seller. The same is true of the warranty of fitness. Some states have, however, abolished the requirement of vertical privity altogether in actions for breach of warranties. (Salvador v. Atlantic Steel Boiler Co. (457 Pa. 319 (1974)).

- Alternatives B and C have been applied to bystanders.

- Alternative $\mathrm{C}$ has been held to cover monetary damages sustained by a corporation.

4.5 Limitations on Liability: Disclaimers, Damage Limitations, Time Limitations and Notice

Section 2-316: "Exclusion or Modification of Warranties

1. Words or conduct relevant to the creation of an express warranty or words or conduct tending to negate or limit a warranty shall be construed wherever reasonable as consistent with each other; but subject to the provisions of this Article on parol or extrinsic evidence, negation or limitation is inoperative to the extent that such construction is unreasonable. 
2. Subject to subsection (3), to exclude or modify the implied warranty of merchantability or any part of it, the language must mention merchantability and in the case of a writing must be conspicuous, and to exclude or modify any implied warranty of fitness, the exclusion must be by a writing and conspicuous. Language to exclude all implied warranties of fitness is sufficient if it states, for example, that "There are no warranties which extend beyond the description of the face hereof."

3. Notwithstanding subjection (2),

a. Unless the circumstances indicate otherwise, all implied warranties are excluded by expressions like "as is," "with all faults," or other language which in common understanding calls the buyer's attention to the exclusion of warranties and makes plain that there is no implied warranty; and

$b$. When the buyer before entering into the contract has examined the goods or the sample or model as fully as he desired or has refused to examine the goods, there is no implied warranty with regard to defects which an examination ought in the circumstances to have revealed to him; and

c. An implied warranty can also be excluded or modified by course of dealings or course of performance or usage of trade.

4. Remedies for breach of warranty can be limited in accordance with the provisions of this Article on liquidation or limitation [repair, replacement, return of the article] of damages and on contractual modification of remedy."

\subsubsection{Notes on limitations of warranties:}

- Many (if not most) states now require that any exclusion be in writing.

- Conspicuous is defined as (Section 1-201(10)):

"A term or clause is conspicuous when it is so written that a reasonable person against whom it is to operate ought to have noticed it. Language in the body of a form is "conspicuous" if it is in larger or other contrasting type or color. But in a telegram any stated term is "conspicuous." Whether a term or clause is "conspicuous" or not is for decision by the court." 
- There is a split as to whether "as is" disclaimers must likewise be conspicuous.

- A "fire sale" or an "unclaimed freight" sale might be an example where a warranty might be excluded because of trade usage.

- A post-sale disclaimer is difficult to uphold because it is a heavy burden to prove that a buyer would actually agree to be bound by a post-sale modification! Why would a buyer agree to any post-sale modification that would limit his/her chances of recovery?

- It is almost impossible to orally disclaim an express warranty once it has been offered. Such an "oral disclaimer" would almost always be subject to the parol evidence rule.

\subsection{Contractual Modification or Limitation of Remedy (Section 2-719)}

1. Subject to the provisions of subsection 2 and 3 of this section and of the proceeding section on liquidation and limitation of damages,

a. The agreement may provide for remedies in addition to or in substitution for those provided in this Article and may limit or alter the measure of damages recoverable under this article, as by limiting the buyer's remedies to return of the goods and repayment of the price or to repair and replacement of nonconforming goods or parts; and

b. Resort to a remedy as provided is optional unless the remedy is expressly agreed to be exclusive, in which case it is the sole remedy.

2. Where circumstances cause an exclusive or limited remedy to fail of its essential purpose, remedy may be had as provided in this act.

3. Consequential damages [for lost profits or personal injury] may be limited or excluded unless the limitation or exclusion is unconscionable. Limitation of consequential damages for injury to the person in the case of consumer goods [goods purchased for "personal, family, or household use"] is prima facie unconscionable but limitation of damages where the loss is commercial [for producer goods or for injury to property] is not.

\subsubsection{Notes on Contractual Limitations:}

- In a case where a consumer good causes personal injury, a limitation to "repair only" would "fail the essential purpose" of the Act and would not be enforced. (Soo Line R.R. Co. v. Fruehauf Corp., 547 F.2d 1365 ( $8^{\text {th }}$ Cir. 1977)). 
- Warranties can be limited in terms of time provided that the period is deemed reasonable. Think about the range of "time limitations" in automobile warranties.

- Subsection 2-607 (23) (a) provides that the buyer must "within a reasonable time after he discovers or should have discovered any breach notify the seller of breach or be barred from any remedy." This is usually no more than 3 months.

- This notice requirement is not the same as the Statute of Limitations requirement. Under Section 2-725, the Statute of Limitations may never be reduced to a period less than one year and may extend to a period of four years. In general, the Statute of Limitations for filing a suit for a breach of warranty begins from the date of the breach of warranty, regardless of the aggrieved party's lack of knowledge of the breach. The contractual warranty period begins when the tender of delivery is made.

- Notwithstanding the above, a few courts have marked the statute of limitations from the date of discovery of an injury or from the date when the injury should have been discovered in a breach of warranty case involving personal injury as a matter of "public policy." Individual state law should be consulted as to this issue.

- Several states have adopted "statutes of repose" of ten or twenty years as an absolute time period after which the seller/manufacturer may not be held liable, but their application is highly speculative in light of the discussion above.

- In practical terms, you must first determine if a warranty provision is applicable (especially relevant in a horizontal extension of warranty provisions to employees or customers of the buyer of producer goods) and then determine if a disclaimer is valid. If a warranty provision extends to an employee or to another party, it would be difficult to prove that a disclaimer should apply to that party without express agreement of that party.

It is important to note that a statute of repose would put an absolute time limit on the amount of time a manufacturer might be liable under any one or more of the theories in a products liability suit. These statutes are sought vigorously by, for example, the airplane-manufacturing sector, which has lobbied for an absolute 20-year statute of repose in the sale or resale of airplanes.

\section{Strict Liability}

The following language may be found in the seminal case of Greenman v. Yuba Power Products, Inc., 27 Cal. Rptr. 697 (1963):

"A manufacturer is strictly liable in tort when an article he places on the market, knowing that it to be used without inspection for defects, proves to have a defect that causes injury to a human being." 
"Although...strict liability has usually been based on the theory of an express or implied warranty running from the manufacturer to the plaintiff, the abandonment of the requirement between them, the recognition that the liability is not assumed by agreement but imposed by law... and the refusal to permit the manufacturer to define the scope of his own responsibility for defective products... make clear that the liability is not one governed by the law of contract warranties but by the law of strict liability in tort."

"The purpose of such liability is to insure that the costs of injuries resulting from defective products are borne by the manufacturers that put such products on the market rather than by the injured persons who are powerless to protect themselves."

"To establish the manufacturer's liability it was sufficient that plaintiff proved that he was injured while using the Shopsmith in a way it was intended to be used as a result of a defect in design and manufacture of which plaintiff was not aware that made the Shopsmith unsafe for its intended use."

\subsection{The Historical Development of the Theory of Strict Liability in Tort}

Before the Greenman decision in 1963, a plaintiff in a products liability case had to rely on the theories of negligence, breach of warranty, or misrepresentation or fraud for recovery. These theories were not specific to products cases and presented plaintiffs with certain formidable "obstacles." As a brief review, recall that negligence required that a plaintiff normally prove a specific act or omission on the part of a defendant and was subject to the harsh defense of contributory negligence, often an absolute bar to recovery. Warranties required a plaintiff to contend with the issues of privity, notice, and disclaimers. Under the theories of misrepresentation and fraud, a plaintiff had to plead and prove justifiable reliance on specific assertions or statements of the defendant.

In 1944, in Escola v. Coca Cola Bottling, 24 Cal. 2d 453 (1944), a res ipsa loquitur case, Justice Traynor argued in his concurring opinion that these traditional theories were inadequate and that the court should adopt a new and special theory for product cases. "In my opinion, it should now be recognized that a manufacturer incurs an absolute liability when an article he has placed on the market, knowing that it is to be used without inspection, proves to have a defect that causes injury to human beings." Judge Traynor points out that a type of strict liability is already imposed on products sellers under the law of warranty (merchantability). The privity requirement, however, rendered the remedy inadequate because most consumers could not, at that pre-Henningsen time (1960), sue the manufacturer of the harmful product because they were not in privity of contract with the manufacturer.

Today, courts are continuing to work out the details of strict liability, by addressing such issues as defenses (misuse, extension of contributory negligence, assumption of risk, etc.) 
causation, scope of duty, and the applicability and extension of strict tort liability to particular products, sellers, and situations.

In 1965, the American Law Institute embraced the Greenman principle in Section 402A of the Restatement (Second) of Torts.

"1. One who sells any product in a defective condition unreasonably dangerous to the user or consumer or to his property is subject to liability for physical harm thereby caused to the ultimate user or consumer, or to his property, if

a. The seller is engaged in the business of selling such a product, and

$b$. Is expected to and does reach the user or consumer without substantial change in the condition in which it is sold.

\section{The rule applies although:}

a. The seller has exercised all possible care in the preparation and sale of his product, and

$b$. The user or consumer has not bought the product from or entered into any contractual relation with the seller."

The Greenman decision, coupled with Section 402A (originally thought to apply only to food and drink cases), provided the "intellectual basis" for the transition from warranty to strict liability in tort and represented the beginning of modern products liability law. A great many developments have taken place since 1965 and, as a result, many courts have departed substantially from the original Restatement rule. Each state is free to interpret Section 402A and to expand this important concept on a case-by-case basis. There is no "national product liability law" at this time!

It is apparent that the philosophy articulated by Justice Traynor in the Greenman decision has been followed in the Restatement version of the strict liability standard. Subsection (2) is clearly intended to place responsibility for safe products on the seller or manufacturer rather than an unknowing user or consumer. Further, Section 402A continues to remove the requirement of proof of fault as did Greenman. However, Section 402A adds the condition that the product be unreasonably dangerous to the Greenman standard. This addition has generated some significant controversy. This has led a variety of jurisdictions to adopt the Greenman standard rather than purely Section 402A.

As a general rule, the basic elements of strict products liability cases may be expressed as follows:

- The defendant was in the business of producing or selling the product [status as a merchant]; 
- The product was expected to and did reach the purchaser without substantial change in the condition in which it was sold;

- The product was defective [in design, manufacture, or warnings] when it left the defendant's control;

- The harm resulted when the product was being used in a reasonable foreseeable manner;

- The person harmed was foreseeable [later expanded to include a bystander]; and

- The defect was the cause in fact and proximate cause [legal cause] of physical harm to the plaintiff's person or property.

5.2. Policies Underlying Strict Liability (Fischer \& Powers, pp. 50-51 (1988)

Courts, commentators, scholars and even professors have advanced a variety of "policy justifications" for the imposition of strict tort liability. The following are the most prevalent and are summarized briefly for your consideration:

- Loss Spreading: It is humane and fair to shift losses from an individual to all consumers of a product by imposing strict liability on manufacturers, thus, forcing manufacturers to insure against losses or to spread potential losses among all purchasers through appropriate pricing policies.

- Deterrence/Incentive: Imposing strict liability on manufacturers provides them with an incentive to market safer products. Strict liability induces manufacturers to go beyond traditional negligence standards of a "reasonable person," especially if the cost of the added safety measures is less than the potential cost of liability for failure to take them (cost/benefit, risk/utility analysis) - most especially if the cost of any change or modification is minimal.

- Encouraging Useful Conduct: Strict liability, based upon reasonable concepts of risk/utility (recognizing that there is some risk in all areas of human activity), will still encourage manufacturers to produce useful products. At its core, a plaintiff will not be compensated simply because he has been injured; rather, a plaintiff will still need to prove that a defect exists, thus holding out to the manufacturer that proper conduct will not be punished.

- Proof Problems: Modern complexities in manufacturing make it very difficult to establish negligence, especially since the manufacturer is usually at a relative advantage in terms of access to expertise, information, and resources. Strict liability frequently will eliminate a plaintiff's need to prove a particular element of a case, such as the existence of negligence, or may eliminate proof of identity of a defendant through the imposition of enterprise liability. 
- Protection of consumer expectations: Since modern advertising and marketing techniques induce consumers to rely on manufacturers to provide them with safe, high quality products, consumers should come to expect protection from unknown dangers in products, best exemplified through the imposition of strict liability.

- Cost Internalization: Forcing manufacturers to compensate victims of defective products through the purchase of appropriate products liability insurance or by making an enlightened decision to essentially "self insure" will lead to a more efficient allocation of resources and pricing of products to include all of their true costs, including the causes associated with damages caused by defective products. If funds are already available from which injured parties can be compensated, manufacturers will be more apt to admit liability rather than "stonewall" in handling complaints of product defects.

\section{Some Concluding Commentary}

Products liability has come a long way since its origins in doctrines that essentially protected a manufacturer and a retailer from liability for defective products based on the rather arcane concepts of privity of contract or limitations on duties in traditional negligence-based cases. Because of these limitations, plaintiffs, but not necessarily courts, moved quickly to craft a variety of theories under which a manufacturer could be held liable if one of its products was found to be defective. As a result, plaintiffs relied on theories of negligence, no longer bound by privity considerations, fraud and misrepresentation, or warranty to press their claims. However, because each of these theories contained inherent negatives, Judge Traynor (among others) led the successful fight to place responsibility squarely on the shoulders of those who placed defective products on the market - thus creating the theory of strict liability in tort.

While strict liability is now accepted as the preferred theory in products cases, it has yet to work out its reaches or limitations. Thus, there are still significant differences between jurisdictions in allocating responsibilities between defendants, establishing the nature of transactions subject to strict liability, or concurring as to the nature of the appropriateness of certain types of damages in strict liability cases. Thus, the story of strict liability is yet to be completely written!

\section{REFERENCES}

Bergeron v. Dupont, 116 N.H. 373 (1973)

DeLuryea v. Winthrop Laboratories, 697 F.2d 222 ( $8^{\text {th }}$ Cir. 1983)

Escola v. Coca Cola Bottling Co. of Fresno, 24 Cal. 2d 453 (1944) 
Fisher, David A. \& Powers, William. Products liability: cases and materials. St. Paul, Minn.: West Publishing Co. (1988)

Garnes v. Gulf \& Western Manufacturing Co. 789 F.2d 637 ( $8^{\text {th }}$ Cir. 1985)

Greenman v. Yuba Power Products, Inc., 27 Cal. Rptr. 697 (1963)

Hall v. E.I DuPont, 237 F.2d $145\left(4^{\text {th }}\right.$ Ct. 1956)

Henningsen v. Bloomfield Motors, 32 N.J. 358 (1960)

Lewis v. Mobil Oil, 438 F.2d $500\left(8^{\text {th }}\right.$ Cir. 1971)

Loop v. Litchfield, 42 N.Y. 351 (1970)

MacPherson v. Buick Motors, 217 N.Y. 382 (1916)

Puckett Paving v. Carrier Leasing, 236 Ga. 891 (1976)

Salvador v. Atlantic Steel Boiler Co. (457 Pa. 319 (1974)

Sellers v. Looper, 264 Ore. 12 (1972)

Siemen v. Alden, 34 Ill. App. 3d 961 (1975)

Soo Line R.R. Co. v. Fruehauf Corp., 547 F.2d 1365 ( $8^{\text {th }}$ Cir. 1977)

Taylor v. Wyeth Labs, 139 Mich. App. 389 (1984)

Thomas v. Winchester, 6 N.Y. 397 (1852)

Vokes v. Arthur Murray, 212 So. 2d 906, D.C. Appl. Fla. (1968)

Yorke v. Taylor, 356 Mass. 42 (1969)

Wilson v. Piper Aircraft, 282 Ore. 411 (1978)

Winterbottom v. Wright, 152 Eng. Rep. 402 (1842) 